\title{
The Law and Ethics of Restitution
}

By Hanoch Dagan, Cambridge: Cambridge University Press, 2004, xxi + 374pp including bibliography and index, ISBN $0521829046 \mathrm{hbk} . £ 55.00$

Review by Peter Jaffey, Professor of Law, Brunel University.

An unjust enrichment claim is generally understood to be a claim arising to correct an event or state of affairs consisting in the receipt or retention of a benefit by the defendant, and restitution is the remedy that corrects it by way of a transfer of the benefit or payment for it to the claimant. There have always been some claims of this sort: for example, the claim to recover a mistaken payment, or other invalid transfers of money or property; the claim to recover a prepayment or for payment for part performance, on the breakdown of a contract; and the claim for payment for a benefit conferred in the absence of a contract, for example in an emergency, as in the case of a salvor saving a ship foundering at sea. Until relatively recently, these various claims did not receive much attention in textbooks or university law courses, and in the case law they often seemed to be treated as a residual miscellany. Nowadays they are in the limelight. Many commentators have argued, or often just assumed, that the reason why these claims were overlooked for so long is that the courts failed to recognise a distinct category of the common law, a third private law category of restitution or unjust enrichment, analogous to contract and tort. In recent English cases, following the lead of the textbooks, the judges have indeed appeared to recognise such a category. But what is the significance of this? Is it just a matter of convenience in the exposition of the law and the administration of practice and teaching, which will help in a practical way to ensure that unjust enrichment claims are not ignored, or does it actually affect the law itself, and legal reasoning over unsettled law?

In this substantial contribution to the literature, focussed on US law, Hanoch Dagan adopts a distinctive approach to this question. In Chapter 1, Dagan outlines his general approach to the common law, which he characterises as pragmatist in the tradition of American Legal Realism (pp. 3-10). One might take this to mean that he regards legal doctrine as just a 'smokescreen' for the extraneous psychological or social factors that really determine how cases are decided. But Dagan denies this; he is not a sceptic about legal doctrine. The important point that he takes from Legal 
Realism is the inadequacy of a formalist or mechanical attitude to rules. $\mathrm{He}$ emphasises that judges should take account of the moral considerations that lie behind the concrete rules of the common law, and mould them accordingly. Dagan also cites Dworkin in support of this approach (pp. 9-10), which seems more apt, though this general idea would surely be widely accepted, and not just by those who regard themselves as either pragmatists or Dworkinians. More distinctively, and more tendentiously, Dagan considers that there are three important broad principles or themes running through the common law: the principles of utility, community, and autonomy (p. 4). These grand principles are the important moral considerations that we find underlying the rules of the common law, and in trying to understand and develop existing rules these are the principles that we should look to.

In Chapter 2, Dagan turns to the significance of the 'principle of unjust enrichment'. He considers first an approach that he attributes to the American scholars Seavey and Scott, ${ }^{1}$ the authors of the first US Restatement on Restitution, and earlier Keener. ${ }^{2}$ This is that the law of unjust enrichment is a category of law whose significance, like that of contract and tort, lies in the fact that it is based on a 'unitary principle' (pp. 1113). The idea is that there is an underlying moral principle - the principle of unjust enrichment - that provides the justification for claims that arise from the receipt of a benefit. This abstract principle is not a substitute for the concrete rules of law that are applied to determine the legal position on particular facts; it provides a general rationale for these rules and a basis for developing them to deal with new circumstances. Thus, as for contract and tort, it makes sense to recognise a generic claim under the category, governed by a standard framework and employing a uniform set of concepts. The upshot (on this approach) is not the immediate emergence of a whole new range of unjust enrichment claims, but the recharacterisation of existing claims in a way that will in due course give effect in a coherent way to the full range of unjust enrichment claims where previously there was only limited and inconsistent recognition. This appears to me to be a common though not the universal understanding of recent developments in English law, in particular the uniform treatment of unjust enrichment claims under a three-stage framework, and the acceptance of unjust enrichment or restitution as a private law category equivalent

\footnotetext{
${ }^{1}$ In particular in Seavey \& Scott (1938).

${ }^{2}$ In particular in Keener (1893).
} 
to contract and tort. ${ }^{3}$ It is difficult to see what other understanding could really account for this. On this approach, the recognition of a category of restitution or unjust enrichment is not simply a matter of convenience of exposition; it is part of the understanding of the principles underlying legal doctrine, and it affects the way the law should be interpreted and how it should develop.

Dagan rejects this approach. His first objection is that the "principle of unjust enrichment' is too vague to provide any guidance; it would give judges an 'unbridled discretion' (p. 16). This is a longstanding objection to the recognition of a principle of unjust enrichment, but it seems difficult to reconcile it with Dagan's own approach, and his reliance on the abstract principles of utility, autonomy and community. Proponents of the principle of unjust enrichment could reasonably respond to him that, as is implicit in his own approach, an underlying principle is not applied in the abstract to a set of facts. The principle supports a body of legal rules, and it is only where there is uncertainty or injustice in these rules that it is necessary to invoke the principle as a guide to the development of the law. The objection of vagueness seems to me the wrong objection to make, and indeed it does not seem to me to get to the heart of Dagan's own concerns about unjust enrichment and restitution.

As I understand his position, Dagan goes further and rejects the whole picture of private law suggested above. He rejects the idea that private law categories such as contract and tort, and still less unjust enrichment or restitution, are based on a 'single normative principle' (pp. 34-35). As I have said, for Dagan the underlying principles that should be brought to bear on the concrete rules of the common law are the principles of autonomy, utility, and community, and on Dagan's approach it seems that this leaves no room for the traditional common law categories to have any significant role, and still less a dominant role, in the interpretation and development of the law. The categories that Dagan uses in the different chapters of his book to structure his treatment of the law are, he says, categories 'rooted in practice and custom, and reflective of existing patterns of human conduct and interaction' (p. 8).

\footnotetext{
${ }^{3}$ See eg Burrows (2002)
} 
Thus although Dagan believes that unjust enrichment claims have received short shrift in the past, on his view the problem is not that the law has failed to recognise a unifying principle of unjust enrichment, or a category of restitution or unjust enrichment law analogous to contract or tort and based on such a principle. According to Dagan the function of a category of restitution or unjust enrichment is to provide 'a loose framework and an invitation to normative inquiry' (p. 26), and thereby to help to 'demarginalise important doctrines' (p. 34); and the concept of unjust enrichment can 'play a modest role as both a loose common theme of the law of restitution and as a reminder of the potential viability of the normative underpinnings of this body of law' (p. 12).

I agree with Dagan that it is misconceived to recognise a category of unjust enrichment or restitution based on a general principle of unjust enrichment in the sense outlined above, and I would add that this implies that the approach that has in recent years gained ascendancy in English law is misconceived. But opposition to this understanding of unjust enrichment does not have to be conjoined with Dagan's general scepticism about the role of the traditional categories of private law. In my view, it is right to understand the categories of contract and tort, and also private property, broadly along the lines of the approach suggested above. Their significance lies in the fact that claims arising in a certain category are analogous to each other because they have a common justificatory basis. This is why such claims are (or ought to be) subject to a standard framework, employing a common set of concepts, and why it makes sense to speak of a generic claim under the category. The problem with the newly recognised category of restitution or unjust enrichment is peculiar to this supposed category: it is that the supposed principle of unjust enrichment is entirely spurious. This does not mean, of course, that the fact that the defendant has received a benefit is irrelevant to the claim or the measure of recovery. It means that its significance is not determined by a 'principle of unjust enrichment', but by different principles in different types of case. Most (though not all) such claims arise in the categories of property and contract, and the relevance of the benefit depends on the nature of the category. ${ }^{4}$ It seems to me that subsequent chapters, in which Dagan deals

\footnotetext{
${ }^{4}$ This was the approach adopted in Jaffey (2000).
} 
with different examples of unjust enrichment claims, lend more support to this understanding than to his own.

In Chapter 3, Dagan discusses the claim to recover a mistaken payment, sometimes described as the archetypal unjust enrichment claim (as in Birks (2005)). Dagan dismisses the idea that the claim is based on a principle of unjust enrichment. Instead he argues that it is based on a principle of autonomy. The claimant's mistake vitiates the transfer, which means that the transfer was not the autonomous act of the claimant. But this can go only part of the way in explaining the claim. The issue of autonomy arises because the claimant has a legal power to transfer his money, and the exercise of the power is vitiated by the mistake. This power is an incident of the claimant's right of ownership of his money, and the claim to recover the payment arises out of this right of ownership. Thus the concept of autonomy is relevant as an aspect of the analysis of the claim as a matter of property law.

It is sometimes objected that the basis of the claim cannot lie in property law, because the claim is not a 'proprietary claim', in the usual sense of this expression by which it means a claim asserting ownership over an asset in the defendant's estate. The claim to recover a mistaken payment has always been a personal rather than a proprietary claim. But this point relates to the nature of the remedy, not the basis for the claim, that is to say, not the underlying principle behind the claim. The basis for the claim surely lies in property law, and this suggests, incidentally, that mistaken payments cases should be treated alongside the proprietary claims that Dagan discusses separately in Chapter 9. Dagan would reject the property-based analysis because, as he makes clear in Chapter 9 (pp. 313-7), he is sceptical about property as the basis for a category of claims in private law. The nature of property in private law is of course too big an issue to pursue here, but one can at least say that Dagan is too quick to jettison private property as the basis for a body of claims in private law. (I offer an account of property-based claims in Jaffey (2007))

Dagan goes on to argue that the principle of utility also contributes to the law of mistaken payments (pp. 52ff). The principle of utility implies that losses arising from a mistaken payment should be allocated in such a way as to lead the parties - or, more precisely, transferors and transferees of mistaken payments in general - to take 
precautions against loss to the optimal extent. With respect to the claimant transferor, this means precautions against making a mistaken payment. With respect to the defendant transferee, it means precautions against consuming or disposing of money (or equivalent value) received through a mistaken payment. It seems to me important to distinguish here between the case where the value of the mistaken payment is still in the defendant's estate, in the form of surplus value derived from the payment, and the case where some or all of the value of the payment has been lost by disposal or consumption by the defendant. In the former case, the claimant should surely be allowed full recovery even if he has failed to take appropriate precautions, since this leaves the defendant as he was before the receipt. The latter case is more problematic. Should the claimant still recover the full amount of the payment, so that the defendant ends up worse off than he would have been if he had never received the payment; or should the claim be limited to the amount by which the defendant remains in surplus as a result of the payment, so as to protect the defendant from any adverse consequences of the receipt (the "change of position" rule); or should the loss be shared? The principle of utility implies that the rule should be such as to minimise the aggregate loss of the parties in the generality of cases. This sort of approach is of course derived from the law and economics literature, where, as Dagan notes, it is most commonly applied in relation to accidents. (It is worth mentioning that broadly the same approach can be understood as a matter of doing justice as between the parties rather than utility or efficiency. ${ }^{5}$ ) However, just as the autonomy approach needs to be understood in relation to property law, so (as seems to be implicit in Dagan's discussion) this utility calculus needs to be understood as a matter of tort law. The law of mistaken payments is a matter of the law of property, insofar as it is concerned with recovering the surplus value remaining in the defendant's estate, and insofar as there is any further claim it is a tort claim based on the failure of the recipient to preserve the money received from the claimant, to which the claimant's fault (or failure to take optimal precautions) may also be relevant as a matter of contributory negligence. ${ }^{6}$ Thus it seems to me that Dagan's analysis demonstrates the significance of property and tort as basic categories of claim in private law.

\footnotetext{
${ }^{5}$ See Dworkin (1986), ch 8.

${ }^{6}$ See further Jaffey (2007), ch 7.
} 
Chapter 8 concerns claims arising on the termination of a valid contract. The usual type of contract claim is the claim for expectation damages, but, as mentioned above, there are other claims, not for expectation damages, that may in some circumstances arise on the breakdown of a contract, such as a claim to recover a prepayment or part of it, or a claim for part-payment for part-performance. Dagan's principal concern here is that any such claim should be consistent with and should not subvert the allocation of risk implicit in the terms of the contract (p. 260). Dagan treats this as a matter of utility, and this may be so; but, more particularly, the issue is how to deal with contingencies that arise from the breakdown of the contract, and the fundamental concern is to resolve matters in a way that is appropriate in the light of the terms agreed between the parties, which implicitly include the allocation of risk. Addressing this issue as a matter of utility is not at odds with the understanding of contract as a category based on a unifying principle; indeed the role of the principle of utility in this type of case surely cannot be understood in any other way. Elsewhere I have analysed these claims as contractual reliance claims; ${ }^{7}$ but, whatever the right contractual analysis, the crucial point in the current English context is that, on the standard approach in the English restitution and unjust enrichment textbooks and possibly now in the courts, these claims are understood, quite implausibly, as noncontractual claims arising from the conditional transfer or transfer on a 'failed basis' of performance under the contract, ${ }^{8}$ and this is certainly liable to undermine the contractual allocation of risk.

Other types of unjust enrichment claim are covered in other chapters. I cannot do justice here to the range of issues Dagan covers or his detailed arguments, but I will mention some other distinctive features of his coverage. In Chapter 5, on the 'selfinterested conferral of benefits', Dagan discusses claims by the state to recover the costs of medical care provided by the state to the victims of 'injurious industries' such as the tobacco or handgun industries, by way of subrogation to the victims' claims against the manufacturers. This is an issue that has apparently gone much further in the US than in the UK. Chapter 6 concerns restitution in 'contexts of informal intimacy', meaning principally claims by one partner or spouse against the other to a share of ownership in the house in which they have lived together. This has been

\footnotetext{
${ }^{7}$ See Jaffey (2000), ch 2.

${ }^{8}$ See eg Burrows (2002), ch 9; Virgo (2006), ch 12.
} 
controversial in all the common law jurisdictions. In English law it has not usually been understood as a matter of unjust enrichment at all, and is generally not covered in the restitution and unjust enrichment literature. Dagan presents an argument for assimilating this type of case with other ostensibly different types of claim more commonly treated in the literature as unjust enrichment claims. In Chapter 9, Dagan discusses the 'remedial constructive trust', and he shows far more sympathy for this approach than it has generally received in the English case law and literature. A distinctive feature of the whole work is the use of economic analysis, which again has not featured prominently in the English literature.

I will end by emphasising two points made earlier. First, Dagan's book does not support the treatment of unjust enrichment claims under a standard framework and with a common set of concepts. This means, I think, that his approach is at odds with recent developments in English law. Dagan mentions that a generation ago unjust enrichment or restitution was a popular subject of study in US law schools, but interest lapsed there just as it caught on in England, and in the US it never became established as a working category in the courts. Dagan celebrates the recent revival of interest in the US, but if this revival follows the pattern of the English case law and literature it will be at odds with Dagan's general approach and it will tend to exclude many of his arguments.

Secondly, on the face of it Dagan's approach marginalises the role of traditional private law categories such as contract and tort, and also private property, in favour of the more abstract principles of utility, autonomy and community. I find this aspect of his work much less convincing. Dagan's arguments do not actually depend on jettisoning the traditional categories of private law. Neither is this required by the need to avoid a formalistic or mechanical approach to the rules of the common law. To the contrary, it seems to me that the arguments Dagan advances about the availability of claims in different circumstances implicitly rely on the distinctions between these categories and the different types of consideration that are relevant to them. Historically the main problem in the analysis of unjust enrichment claims has been the failure to consider when and how such claims arise in the categories of contract and property. This is why these claims were historically sidelined, and this is 
why they will remain a source of confusion and uncertainty for as long as the recent developments in English law continue along the same lines.

\section{References}

Birks, Peter, (2005) Unjust Enrichment Oxford: OUP, $2^{\text {nd }}$ edn.

Burrows, Andrew (2002) The Law of Restitution London: Butterworths, $2^{\text {nd }}$ edn.

Dworkin, Ronald (1986) Law's Empire London: Fontana

Jaffey, Peter (2000) The Nature and Scope of Restitution Oxford: Hart Publishing.

Jaffey, Peter (2007) Private Law and Property Claims Oxford: Hart Publishing.

William A Keener (1893) A Treatise on the Law of Quasi-Contracts, $1^{\text {st }} \mathrm{edn}$.

Warren A Seavey \& Austin W Scott (1938) 'Restitution' 213 LQR 29.

Virgo, Graham (2006) The Principles of the Law of Restitution Oxford: OUP, $2^{\text {nd }}$ edn. 